\title{
DETERMINAN PRICE TO BOOK VALUE SUB SEKTOR MAKANAN DAN MINUMAN TAHUN 2013-2017
}

\author{
Amelinda Frederica
}

Program Studi Magister Akuntansi Universitas Tarumanagara

Email: amelinda1026@gmail.com

Masuk : 01-03-2019, revisi: 26-07-2019, diterima untuk diterbitkan : 30-10-2019

\begin{abstract}
ABSTRAK
Penelitian ini bertujuan untuk menguji pengaruh struktur modal, profitabilitas, dan likuiditas terhadap nilai perusahaan di perusahaan manufaktur sub-sektor makanan dan minuman pada 2013-2017. Sampel yang digunakan adalah 70 sampel yang terdiri dari 14 perusahaan sektor makanan dan minuman dalam periode 5 tahun. Jenis data yang digunakan dalam penelitian ini adalah data panel yang diperoleh dari laporan keuangan perusahaan. Analisis data dilakukan dengan regresi linier berganda dengan bantuan program perangkat lunak Eviews 8 untuk windows. Ketika data penelitian tidak memiliki distribusi normal, analisis regresi linier berganda tidak valid untuk digunakan, sebagai alternatif, yaitu melalui penggunaan metode Robust Regression on Ordered Statistics (ROS). Hasil penelitian ini menunjukkan bahwa struktur modal tidak berpengaruh signifikan terhadap nilai perusahaan, profitabilitas berpengaruh signifikan terhadap nilai perusahaan, likuiditas tidak berpengaruh signifikan terhadap nilai perusahaan.
\end{abstract}

Kata Kunci: struktur modal, profitabilitas, likuiditas, utang terhadap ekuitas, pengembalian aset.

\begin{abstract}
This study aims to examine the effect of capital structure, profitability, and liquidity on firm value in food and beverage sub-sector manufacturing companies in 2013-2017. The sample used was 70 samples consisting of 14 food and beverage sector companies in a 5-year period. The type of data used in this study is panel data obtained from the corporate's financial statements. Data analysis was performed with multiple linear regression with the help of the Eviews 8 for windows software program. When research data do not have a normal distribution, multiple linear regression analysis is invalid to use, as an alternative, namely through the use of the Robust Regression on Ordered Statistics (ROS) method. The results of this study indicate that capital structure has no significant effect on firm value, profitability has a significant effect on firm value, liquidity has no significant effect on firm value.
\end{abstract}

Keywords: capital structure, profitability, liquidity, debt to equity, return on assets.

\section{PENDAHULUAN}

\section{Latar Belakang}

Sektor industri makanan dan minuman menjadi motor pertumbuhan industri pengolahan khususnya non-migas pada 2017 yang ditargetkan tumbuh 5,3\% sampai 5,6\%. Sementara itu, proyeksi pertumbuhan ekonomi baru mencapai 5,1\% sampai 5,4\%, artinya target pertumbuhan ditahun 2017 lebih dari proyeksi pertumbuhannya. Pemerintah optimistis bahwa kondisi perekonomian nasional akan lebih stabil dan membaik, sehingga menumbuhkan iklim investasi yang kondusif bagi sektor industri. https://m.tempo.com(diakses pada 23/07/17).Industri makanan dan minuman menunjukkan pertumbuhan yang cukup signifikan seperti berikut. 
Sumber: Data laporan keuangan diolah

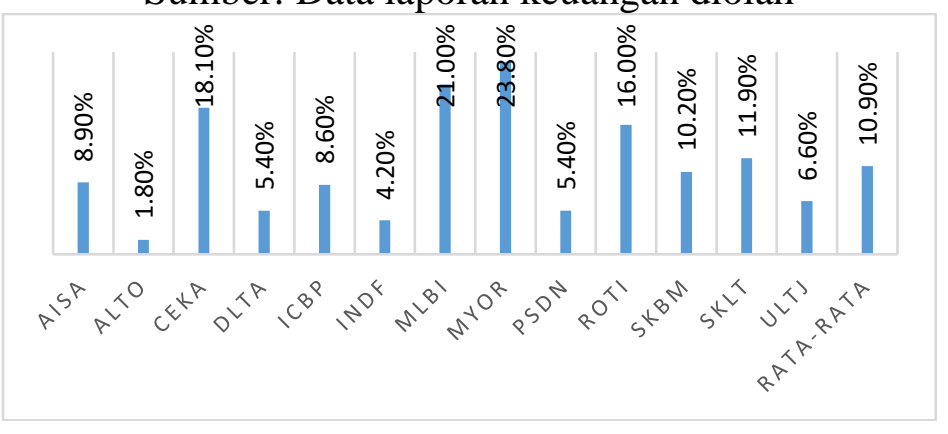

Menurut Airlangga Hartanto sebagai yang dikutip dari Detik Finance (10 Oktober 2017), industri Makanan dan Minuman menjadi salah satu sektor penting dalam perekonomian Indonesia, namun pertumbuhan industri makanan dan minuman di akhir Juni 2017 melambat dibandingkan hasil triwulan I-2017. Pertumbuhan industri makanan dan minuman pada triwulan kedua sebesar $7,19 \%$. Walaupun mengalami sedikit perlambatan bila dibandingkan dengan triwulan I-2017 sebesar 8,15\%.Melalui fenomena ini, sangat dimungkinkan bahwa nilai perusahaan dipengaruhi oleh beberapa faktor, seperti tingkat likuiditas perusahaan maupun komposisi struktur modal yang dimiliki perusahaan dalam menjalankan kegiatan operasionalnya. Beberapa hasil penelitian sebelumnya juga telah melakukan kajian sejenis, namun terdapat ketidakkonsistenan temuan (research gap) seperti yang diuraikan sebagai berikut.

Tabel 1. Research Gap

\begin{tabular}{clll}
\hline No & \multicolumn{2}{c}{ Peneliti } & \multicolumn{2}{c}{ Temuan } & \\
\hline 1 & Hamidy et al. $(2015)$ & Struktur modal berpengaruh & positif \\
& Anjarwati et al. $(2016)$ & terhadap nilai perusahaan & \\
& Lubis et al. (2017) & Struktur modal berpengaruh & positif \\
& Fadhli (2015) & terhadap nilai perusahaan & \\
\hline 2 & Wijaya dan Purnawati & $\begin{array}{l}\text { Likuiditas berpengaruh positif terhadap } \\
\text { nilai perusahaan }\end{array}$ & \\
& (2013) & Likuiditas berpengaruh positif terhadap \\
& Lubis et al. (2017) & nilai perusahaan & \\
& Anjarwati et al. $(2016)$ & &
\end{tabular}

Hasil penelitian terdahulu menunjukkan penemuan yang tidak konsisten, hal ini disebabkan karena adanya faktor lain yang ikut berpengaruh seperti profitabilitas perusahaan. Profitabilitas merupakan ukuran dimana suatu perusahaan mampu menghasilkan laba. Nilai perusahaan dapat dipengaruhi oleh besar kecilnya profitabilitas yang dihasilkan oleh perusahaan, apabila profitabilitas perusahaan baik maka para investor akan melihat sejauh mana perusahaan menghasilkan laba dari penjualan dan investasi peusahaan. Profitabilitas merupakan salah satu faktor yang secara teoritis menentukan nilai suatu perusahaan. Perusahaan yang mampu menghasilkan laba besar dan stabil akan menarik para investor, karena secara otomatis akan menguntungkan investor.

Kemampuan perusahaan yang besar untuk menghasilkan laba juga menunjukkan manajemen perusahaan yang baik, sehingga menumbuhkan kepercayaan pada investor. Kepercayaan investor ini pada akhirnya dapat menjadi instrumen yang paling efektif untuk mengangkat harga saham perusahaan. Peningkatan harga saham sama artinya meningkatkan nilai perusahaan, sehingga lebih lanjut dapat menjamin kemakmuran pemegang saham. Tingkat profitabilitas perusahaan dapat dilihat dari rasio yang menunjukkan kemampuan perusahaan menghasilkan laba atas penggunaan aset perusahaan yaitu return on assets. Beberapa penelitian terdahulu juga telah 
membuktikan bahwa profitabilitas berpengaruh positif dan signifikan terhadap nilai perusahaan (Hamidy et al.,2015; Suranto et al.,2017; Fadhli,2015; Anjarwati et al., 2016).

Dengan demikian dapat diidentifikasikan bahwa pertumbuhan perusahaan sub sektor makanan dan Minuman mengalami pertlambatan di tahun 2017 yang mana pada kuartal I sebesar 8,15\% menjadi $7,19 \%$ di kuartal II. Pertumtuhan ini jauh lebih kecil jika dibandingkan dengan pertumbuhan 2015 menuju 2016 sebesar 10.9\%. Selain itu juga niali price to book value yang menjadi indikator nilai perusahaan ternyata ditemukan beberapa perusahaan yang memiliki nilai price to book value dibawah satu yang artinya nilai saham perusahaan masuk kategori murah, misalnya PT Tiga Pilar Sejahtera Food, Tbk menunjukkan penurunan nilai price to book value pada tahun 2017 menjadi 0,450. Kemudian PT Cahaya Kalbar, Tbk juga menunjukkan penurunan nilai price to book value menjadi 0,850 di tahun 2017. Perurunan. Nilai price to book value menjadi kurang dari satu menjunjukkan adanya penurunan nilai saham perusahaan dari mahal menjadi semakin murah.

Disi lain, ditemukan perbedaan temuan (reseach gap) antara struktur modal (debt to equity ratio, likuiditas (current ratio) dan profitabilitas (return on assets) terhadap nilai perusahaan (price to book value).Penelitian ini bertujuan untuk:

1. Mengetahui dan menjelaskan besarnya pengaruh debt to equityratio terhadap price to book value Sub Sektor Makanan dan Minuman.

2. Mengetahui dan menjelaskan besarnya pengaruh return on assets terhadap price to book value Sub Sektor Makanan dan Minuman.

3. Mengetahui dan menjelaskan besarnya pengaruh current ratio terhadap price to book value Sub Sektor Makanan dan Minuman.

\section{Trade of Theory}

Teori yang dikembangkan oleh Modigliani dan Miller, yang mana teori ini menekankan keseimbangan antara penghematan pajak yang timbul dari hutang dan penurunan biaya agen dan kebangkrutan serta biaya tekanan keuangan (Oruc dalam Shahar et al., 2015). Ehrhardt dan Brigham (2011) menyatakan bahwa nilai dari perusahaan yang diungkit sama dengan nilai perusahaan yang tanpa kendali ditambah nilai efek sampingnya, yang mencakup perisai pajak (tax shield) dan biaya yang diharapkan karena kesulitan keuangan.Trade off theory lebih menekankan keseimbangan antara penghematan pajak yang timbul dari hutang dan penurunan biaya agen dan kebangkrutan serta biaya tekanan keuangan. Perusahaan tanpa menggunakan hutang dalam modalnya akan membayar pajak yang lebih besar daripada perusahaan yang menggunakan hutang, hal ini tentunya dapat membawa perubahan pata aset yang dimiliki perusahaan. Penggunaan utang oleh perusahaan yang lebih besar cocok sebagai ukuran disipliner untuk mengurangi biaya agensi melalui perjanjian utang. Hal ini sesuai trade off theory yang menjelaskan bahwa dengan perusahaan yang memiliki aset tinggi cenderung lebih terdiversifikasi dan mempunyai akses yang lebih besar ke pasar modal serta biaya langsung dari penerbitan utang atau ekuitas lebih kecil.

\section{Packing Order Theory}

Menjelaskan bahwa perusahaan menggunakan dana internal yang lebih murah daripada dana eksternal. Ketika diperlukan dana dari luar, perusahaan lebih menyukai hutang terhadap ekuitas karena informasi lebih rendah biaya yang terkait dengan masalah hutang, sementara ekuitas jarang diterbitkan (Zhao et al., 2004). Jibran et al., (2012) menegaskan bahwa salah satu aspek teori pecking order menyiratkan bahwa ketika menyangkut perusahaan yang menguntungkan, mereka akan selalu memilih pembiayaan internal daripada mengambil hutang baru atau ekuitas 
(pembiayaan eksternal). Meskipun, Utang dianggap lebih murah daripada ekuitas dalam proporsi tertentu.Packing order theory berkaitan dengan ketentuan perusahaan menggunakan dana internal yang lebih murah daripada dana eksternal. Perusahaan dengan profitabilitas yang tinggi akan cenderung tidak menggunakan hutang untuk membiayai investasi. Tingkat keuntungan yang tinggi memungkinkan untuk memperoleh sebagian besar pendapatan dari dana internal. Dalam teori ini juga disebutkan bahwa untuk mencari tambahan dana dengan cara menjual aset yang dimilikinya seperti menjual gedung, tanah, peralatan yang dimiliki dan aset-aset lainnya termasuh dengan menerbitkan dan menjual saham di pasar modal dan dana yang berasal dari laba ditahan.

\section{Struktur Modal}

Dapat didefinisikan sebagai gambaran dari bentuk proporsi finansial perusahaan yaitu antara modal yang dimiliki yang bersumber dari hutang jangka panjang (long-term liabilitas) dan modal sendiri (shareholders equity) yang menjadi sumber pembiayaan suatu perusahaan (Fahmi, (2014). Definisi struktur modal juga disampaikan oleh Paramasivan dan Subramanian (2012), struktur modal adalah pembiayaan permanen perusahaan terutama yang diwakili oleh hutang dan ekuitas jangka panjang. Istilah struktur modal mengacu pada hubungan antara berbagai sumber pembiayaan jangka panjang seperti modal ekuitas, preferensi modal saham dan modal hutang. Dalam memutuskan struktur modal yang sesuai adalah keputusan penting manajemen keuangan karena berkaitan erat dengan nilai perusahaan.Paramasivan dan Subramanian (2012) menyebutkan faktor-faktor pembentuk struktur modal seperti leverage dan biaya modal. Struktur modal dapat diproksikan dengan debt to equity ratio, yang mana rasio ini dapat menilai besarnya utang dengan ekuitas perusahaan.

\section{Profitabilitas}

Menurut Fahmi (2014) menegaskan bahwa rasio ini mengukur efektivitas manajemen secara keseluruhan yang ditujukan oleh besar kecilnya tingkat keuntungan yang diperoleh dalam hubungannya dengan penjualan dan investasi. Kemudian Paramasivan dan Subramanian (2012) memberikan penjelasan bahwarasio profitabilitas dapat membantu mengukur posisi profitabilitas dari masalah bisnis. Brigham dan Houston (2015) memberikan penjelasan bahwarasio profitabilitas, yang memberikan gambaran tentang seberapa menguntungkan perusahaan beroperasi dan memanfaatkan asetnya.Profitabilitas dapat diproksikan dengan beberapa rasio, salah satunya dengan return on assets, yang mana rasio ini digunakan untuk mengukur kemampuan manajemen perusahaan dalam memperoleh keuntungan (laba) atas asset perusahaan.

\section{Likuiditas}

Menurut Fahmi (2014: 59), rasio likuiditas (liquidity ratio) merupakan kemampuan suatu perusahaan memenuhi kewajiban jangka pendeknya secara tepat waktu. Kemudian Brigham dan Houston (2015: 99) memberikan penjelasan bahwabahwa rasio likuiditas, yang memberikan gambaran tentang kemampuan perusahaan untuk melunasi utang yang jatuh tempo dalam setahun. Rasio likuiditas sering disebut sebagai rasio modal kerja dan merupakan rasio yang digunakan untuk mengukur seberapa likuidnya suatu perusahaan (Kasmir, 2017).Rasio likuiditas dapat diukur dengan berbagai rasio seperti current ratio yang mana rasio ini mengukur kemampuan perusahaan dalam membayar kewajiban jangka pendek atau hutang yang segera jatuh tempo pada saat ditagih secara keseluruhan (Kasmir, 2017).

\section{Nilai Perusahaan}


Dalam aktivitasnya, perusahaan memiliki tujuan utama yaitu memeaksimalkan keuantungan ataupun kekayaan, terutama bagi para pemegang saham. Hal ini dapat terwujut melalui upaya peningkatan atau memaksimalkan nilai pasar atas harga saham perusahaan yang bersangkutan. Menurut Fama (1978), nilai perusahaan akan tercermin dari harga sahamnya. Harga pasar dari saham perusahaan yang terbentuk antara pembeli dan penjual disaat terjadi transaksi disebut nilai pasar perusahaan, karena harga pasar saham dianggap cerminan dari nilai aset perusahaansesungguhnya. Memaksimalkan nilai perusahaan sangat penting artinya bagi suatu perusahaan, karena dengan memaksimalkan nilai perusahaan berarti jugamemaksimalkan kemakmuran pemegang saham yang merupakan tujuan utama perusahaan (Euis dan Taswan, 2002). Nilai perusahaan sering diproksikan dengan price to book value yakni hasil perbandingan antara harga saham dengan nilai buku per lembar saham. Menurut Darmaji dan Fakhrudin (2001), price to book value (PBV) merupakan rasio yang menggambarkan seberapa besar pasar pasar menghargai nilai buku saham suatu perusahaan.

\section{Hipotesis}

Setiap perusahaan memerlukan modal (dana) dalam menjalankan kegiatan operasional perusahaan. Pengelolaan dana yang baik akan berdampak baik bagi perusahaan. Kegiatan pengelolaan sumber dana dimulai dari perencanaan akan kebutuhan dana, kemudian diikuti oleh pelaksanaan pencairan sumber dana dan pengendalian atau pengawasan terhadap sumber-sumber dana yang tersedia. Struktur modal memiliki peranan yang penting bagi kelangsungan perusahaan, terutama ketika perusahaan bermaksud melakukan ekspansi maka perusahaan harus menentukan berapa besarnya modal yang diperlukan untuk membiayai usahanya. Struktur modal terdiri dari komponen hutang dan modal sendiri. Besarnya hurang tentunya akan baik, karena banyak investor yang mempercayakan kepemilikannya terhadap perusahaan tertentu, namun masih dalam batas kewajaran dan seiring dengan kinerja perusahaan tersebut. Sebaliknya ketika perusahaan memiliki hutang yang jauh dari komposisi modal perusahaan maka akan cenderung mengalami permasalahan, karena sebagian besar pendapatan yang diperoleh digunakan untuk membayar hutangnya, terutama hutang janka pendeknya. Umumnya tingkat utang perusahaan akan sebanding dengan ekuitas perusahaan, karena telah melewati banyak kajian sebelum perusahaaan memutuskan untuk menerbitkan kebijakan utangnya. Penelitian Hamidy et al. (2015) menegaskan bahwa struktur modal akan mempengaruhi nilai perusahaan. hal ini juga didukung oleh penelitian Anjarwati et al. (2016) yang menyebutkan bahwa struktur modal berpengaruh positif terhadap nilai perusahaan. Struktur modal dapat diproksikan dengan debt to equity ratio dan nilai perusahaan dapat diproksikan dengan price to book value, dirumuskan hipotesis berikut.

H1 : Debt ro equity ratio berpengaruh signifikan terhadap price to book value

Profitabilitas merupakan ukuran dimana suatu perusahaan mampu menghasilkan laba. Kemampuan perusahaan yang besar untuk menghasilkan laba juga menunjukkan manajemen perusahaan yang baik, sehingga menumbuhkan kepercayaan pada investor. Kepercayaan investor ini pada akhirnya dapat menjadi instrumen yang paling efektif untuk mengangkat harga saham perusahaan. melalui peningkatan harga saham perusahaan maka akan membawa nilai yang positif, terutama bagi para investor. Hal ini didukung oleh hasil penelitian yang dilakukan oleh Hamidy et al. (2015) yang menyatakan bahwa profitabilitas berpengaruh positif dan signifikan terhadap nilai perusahaan. Sejalan dengan ini, penelitian lain juga ikut menegaskan bahwa profitabilitas memiliki pengarug yang signifikan terhadap nilai perusahaan (Fadhli,2015; Anjarwati et al., 2016). Profitabilitas dapat diproksikan dengan return on assets dan nilai perusahaan dapat diproksikan dengan price to book value, dirumuskan hipotesis berikut.

$\mathrm{H} 2$ : Return on assets berpengaruh signifikan terhadap price to book value 
Likuiditas berkaitan dengan tingkat kemampuan perusahaan untuk memenuhi kewajiban finansialnya yang harus segera dipenuhi. Likuiditas perusahaan menunjukkan kemampuan untuk membayar kewajiban finansial jangka pendek tepat pada waktunya. Likuiditas perusahaan ditunjukkan oleh besar kecilnya aktiva lancar yaitu aktiva yang mudah untuk diubah menjadi kas yang meliputi kas, surat berharga, piutang, dan persediaan. Perusahaan menginginkan laba yang besar dari hasil penjualannya, karena semakin besar penjualan barang usaha semakin tinggi prifitabilitas yang didapat, keuntungan tinggi membuat nilai perusahaan menjadi tinggi dan menjadi sejahtera. Perusahaan dituntut untuk meningkatkan efesien kerja sehingga dapat mecapai tujuan perusahaan yaitu mendapat keuntungan. Semakin perusahaan tersebut likuid dalam memenuhi hutang jangka pendeknya maka akan meningkatkan kepercayaan investor, sehingga nilai perusahaan akan dapat meningkat. Lubis et al. (2017) menyebutkan bahwa, likuiditas yang tinggi dapat menimbulkan resiko biaya modal yang rendah apabila dana-dana di perusahaan dapat digunakan dengan baik, sehingga investor akan melihat itu sebagai sinyal positif. Kondisi ini dapat diartikan bahwa, nilai aktiva lancar (yang segera dapat dijadikan uang) dengan perbandingan hutang jangka pendek memberikan pengaruh positif dalam meningkatkan nilai perusahaan. Penelitian Siregar (2010) menemukan secara parsial dan simultan likuiditas memiliki pengaruh terhadap nilai perusahaan yang tercermin pada harga sahamnya.Likuiditas dapat diproksikan dengan current ratio dan nilai perusahaan dapat diproksikan dengan price to book value, dirumuskan hipotesis berikut.

H3 : Current ratio berpengaruh signifikan terhadap price to book value

Model konseptuan yang dikembangkan sebagai berikut.

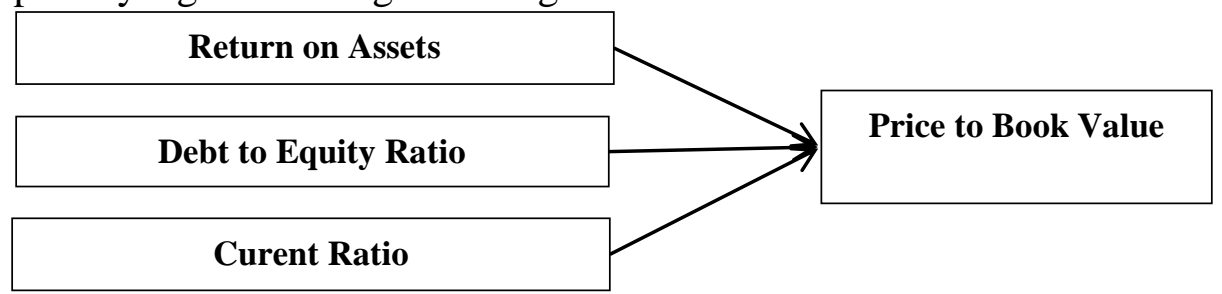

Gambar 2. Model Konseptual

\section{METODE PENELITIAN}

Desain penelitian yaitu desain kausalitas dengan pendekatan penelitian kuantitatif. Penelitian menggunakan dua jenis variabel yaitu variabel independen dan variabel dependen dengan pengukuran:

Price to book value (PBV) merupakan rasio yang menggambarkan seberapa besar pasar pasar menghargai nilai buku saham suatu perusahaan (Darmaji dan Fakhrudin, 2001). Price to Book value (CR) yang dapat dihitung dengan rumus:

$$
P B V=\frac{\text { harga pasar per saham }}{\text { nilai buku per lembar saham }}
$$

Debt to equity ratio merupakan rasio yang digunakan untuk menilai utang dan ekuitas (Kasmir, 2017). Debt to equity ratio (DER) yang dapat dihitung dengan rumus:

$$
D E R=\frac{\text { total tebt }}{\text { total equity }}
$$


Rasio return on assets, digunakan untuk mengukur kemampuan manajemen perusahaan dalam memperoleh keuntungan (laba) atas aset yang dimiliki (Kasmir, 2017).Returnon Assets (ROA) yang dapat dihitung dengan rumus:

$$
R O A=\frac{\text { earning after interest and tax }}{\text { total Aset }}
$$

Rasio lancar (current ratio) merupakan rasio yang mengukur kemampuan perusahaan dalam membayar kewajiban jangka pendek atau hutang yang segera jatuh tempo pada saat ditagih secara keseluruhan (Kasmir, 2017: 134).Current Ratio (CR) yang dapat dihitung dengan rumus:

$$
C R=\frac{\text { current assets }}{\text { current liability }}
$$

Populasi dalam penelitian ini merupakan semua perusahaan Manufaktur Sub Sektor Makanan dan Minuman yang terdaftar di BEI periode 2013-2017 yang berjumlah 16 perusahaan. Sampel ditentukan dengan teknik purposive sampling dengan ketentuan berikut.

Tabel 2.Kriteria Pemilihan Sampel

Sumber: diolah Peneliti (2018)

\begin{tabular}{lc}
\hline \multicolumn{1}{c}{ Kriteria } & Jumlah \\
\hline 1. Perusahaan manufaktur sub sektor makanan dan minuman & 16 \\
yang terdaftar di BEI periode 2013 - 2017 & 14 \\
2. Perusahaan yang menyediakan laporan lengkap pada periode & \\
$2013-2017$ & 14 \\
3. Data yang tersedia untuk dianalisis & 14 \\
Jumlah Sampel & 70 data \\
\hline
\end{tabular}

Data dikumpulkan melalui laporan keuangan yang dipublikasi dalam laman Bursa Efek Indonesia. Data dianalisis dengan regresi linear melalui metode Robust Regression on Ordered Statistics (ROS) dan dilakukan dengan bantuan software eviews 8 for windows.

\section{HASIL DAN PEMBAHASAN}

Robust regression adalah metode regresi yang digunakan ketika distribusi residual tidak normal atau ada beberapa outlier yang mempengaruhi model (Susanti et al. 2014). Data dalam penelitian ini yaitu data yang tidak berdistribusi normal, sehingga dilakukan dengan analisis dengan Metode Robust Regression on Ordered Statistics (ROS). Dalam analisis ini tersedia tiga model estimasi, dan ditentukan model terbaik berikut.

Tabel 3. Nilai R Square Model ROS

Sumber: Data laporan keuangan diolah (2018)

\begin{tabular}{clc}
\hline No & \multicolumn{1}{c}{ Estimasi } & R Square \\
\hline 1 & M-Estimation & 0,133981 \\
2 & S-Estimation & 0,118262 \\
3 & MM-Estimation & 0,079509 \\
\hline
\end{tabular}

Berdasarkan data di atas diketahui bahwa model estimasi yang memiliki nilai R Square terbesar yaitu model M-Estimation yaitu sebesar 0,133981. Dengan demikian model M-Estimation 
merupakan model terbaik dalam menjelaskan variabel terikatnya dibandingkan dengan model $S$ Estimation maupun MM-Estimation. Hasil analisis dengan metode regresi robust M-estimation selengkapnya disajikan dalam tabel berikut.

Tabel 4. Regresi Robust M-Estimation

\begin{tabular}{lrrrr}
\hline \hline \multicolumn{1}{c}{ Variable } & Coefficient & Std. Error & z-Statistic & Prob. \\
\hline \hline C & 0.500689 & 0.951626 & 0.526141 & 0.5988 \\
Debt to Equity Ratio & 0.917515 & 0.596093 & 1.539214 & 0.1238 \\
Return on Assets & 0.238017 & 0.017676 & 13.46573 & 0.0000 \\
Current Ratio & -0.179976 & 0.200325 & -0.898421 & 0.3690 \\
\hline \hline
\end{tabular}

Robust Statistics

\begin{tabular}{llll}
\hline \hline R-squared & 0.133981 & Adjusted R-squared & 0.094616 \\
Rw-squared & 0.458691 & Adjust Rw-squared & 0.458691 \\
Akaike info criterion & 87.82812 & Schwarz criterion & 99.54949 \\
Deviance & 273.5651 & Scale & 1.820360 \\
Rn-squared statistic & 191.1870 & Prob. (Rn-squared stat.) & 0.000000 \\
\hline \hline
\end{tabular}

Non-robust Statistics

\begin{tabular}{llll}
\hline Mean dependent var & 3.738371 & S.D. dependent var & 5.337768 \\
S.E. of regression & 4.394275 & Sum squared resid & 1274.437 \\
\hline
\end{tabular}

Sumber: Data laporan keuangan diolah (2018)

Price to Book Value $=0,500689+0,917515$ Debt to Equity ratio + 0,238017 Return on Assets - 0,179976 Current Ratio + 0,866019

\section{Pengaruh Debt to equity ratio terhadap Price to book value}

Hasil uji regresi robust dengan metode M-estimation menghasilkan nilai koefisien regresi yaitu 0,917515 dan nilai t hitung 1,539214 dengan nilai signifikansi 0,1238 . Hipotesis dalam uji ini dinyatakan ditolak, hal ini dikarenakan nilai signifikasi yang lebih dari $5 \%(0,1238>0,05)$. Artinya debt to equity ratio tidak berpengaruh secara signifikan terhadap price to book value. Nilai koefisien regresi $\left(\beta_{1}\right)=0,917515$ yang memperlihatkan arah pengarug positif (searah) meskipun tidak signifikan. Ketika variabel debt to equity ratio perusahaan bertambah satu poin maka akan meningkatkan price to book value sebesar 0,917515 poin. Hasil penelitian ini kurang sejalan dengan penelitian Anjarwati et al. (2016) yang menyebutkan bahwa debt to equity ratio berpengaruh positif dan signifikan terhadap price to book value. Debt to equity ratio yang diukur dengan debt to equity ratio memberikan gambaran mengenai besarnya hutang dibandingkan dengan modal sendiri. Fadhli (2015) juga menyebutkan bahwa debt to Equity ratio Ratio (DER) tidak memiliki pengaruh signifikan terhadap price to book value. Tingginya hutang menandakan kepercayaan investor pada perusahaan, namun masih dalam batas kemampuan perusahaan. Karena dengan rasio hutang yang sangat tinggi dibandingkan dengan ekuitas perusahaan akan menyulitkan perusahaan dalam mendistribusikan labanya, mengingat sebagian besar pendapatan yang diperoleh dapat digunakan untuk membayar gutang yang jatuh tempo.

\section{Pengaruh Return on assets terhadap Price to book value}

Hasil uji regresi robust dengan metode $M$-estimation menghasilkan nilai koefisien regresi yaitu 0,238017dan nilai t hitung 13,46573 dengan nilai signifikansi 0,000. Hipotesis dalam uji ini dinyatakan ditolak, hal ini dikarenakan nilai signifikasi yang lebih kecil dari $5 \%(0,000<0,05)$. 
Artinya return on assets berpengaruh secara signifikan terhadap price to book value. Nilai koefisien regresi $\left(\beta_{2}\right)=0,238017$ yang memperlihatkan arah pengaruh positif (searah) dan secara signifikan. Ketika variabel return on assets bertambah satu poin maka akan meningkatkan price to book value sebesar 0,238017 poin. Hal ini didukung oleh hasil penelitian yang dilakukan oleh Hamidy et al. (2015) yang menyatakan bahwa return on assets berpengaruh positif dan signifikan terhadap price to book value. Sejalan dengan ini, penelitian lain juga ikut menegaskan bahwa return on assets memiliki pengaruh yang signifikan terhadap price to book value (Suranto et al.,2017; Fadhli,2015; Anjarwati et al., 2016). Return on assets merupakan ukuran dimana suatu perusahaan mampu menghasilkan laba. Kemampuan perusahaan yang besar untuk menghasilkan laba juga menunjukkan manajemen perusahaan yang baik, sehingga menumbuhkan kepercayaan pada investor. Kepercayaan investor ini pada akhirnya dapat menjadi instrumen yang paling efektif untuk mengangkat harga saham perusahaan. melalui peningkatan harga saham perusahaan maka akan membawa nilai yang positif, terutama bagi para investor.

\section{Pengaruh Current ratio terhadap Price to book value}

Hasil uji regresi robust dengan metode $M$-estimation menghasilkan nilai koefisien regresi yaitu 0,179976 dan nilai t hitung -0,89842 dengan nilai signifikansi 0,3690. Hipotesis dalam uji ini dinyatakan ditolak, hal ini dikarenakan nilai signifikasi yang lebih besar dari $5 \%(0,3690>$ 0,05). Artinya current ratio tidak berpengaruh secara signifikan terhadap price to book value. Nilai koefisien regresi $\left(\beta_{3}\right)=-0,179976$ yang memperlihatkan arah pengarug negatif yang sangat kecil dan tidak signifikan signifikan. Ketika variabel current ratio bertambah satu poin maka menurunkan price to book value sebesar 0,179976 poin. Hasil penelitian ini bertolak belakang dengan penelitian Siregar (2010) yang menemukan secara parsial dan simultan current ratio memiliki pengaruh terhadap price to book value yang tercermin pada harga sahamnya. Akan tetapi sejalan dengan penelitian Wijaya dan Purnawati (2013) Current ratio berpengaruh negatif terhadap price to book value, meskipun dalam penelitian ini tingkat pengaruhnya tidak signifikan. Current ratioberkaitan dengan tingkat kemampuan perusahaan untuk memenuhi kewajiban finansialnya yang harus segera dipenuhi. Current ratio perusahaan menunjukkan kemampuan untuk membayar kewajiban finansial jangka pendek tepat pada waktunya. Namun demikian, adanya piutang tak tertagih dan persediaan yang belum dijual dapat menyebabkan tingginya current ratio. Jika hal tersebut lebih mendominasi komponen aktiva lancar lainnya tentunya ini berdampak pada current ratio perusahaan akan tinggi dan seolah-olah perusahaan berada dalam kondisi yang likuid.

\section{Pengaruh Debt to Equity Ratio, Return on Assets dan Current ratio terhadap Price to book value}

Dalam regresi robust tidak memberikan output $\mathrm{F}$ hitung, sehingga dilakukan secara manual. Uji statistik F dapat dicari dengan rumus berikut (Ikhsan, 2015: 158).

$$
F=\frac{R^{2} / k}{\left(1-R^{2}\right) /(n-k-1)}
$$

Dimana nilai $\mathrm{R}$ Square $=0,185382$ dan jumlah variabel bebas $(\mathrm{k})=3$ diperoleh bahwa:

$$
F \text { hitung }=\frac{0,133981 / 3}{(1-0,133981) /(70-3-1)}=\frac{0,04466}{0,866019 / 66}=\frac{0,04466}{0,01312}=3,6098
$$

Hasil uji regresi robust dengan metode $M$-estimation diperoleh nilai $\mathrm{F}_{\text {hitung }}=3,6098$. Sementara itu, nilai $F_{\text {tabel }}=F_{0,05 ; 3 ; 66}=2,75$. Dengan demikian terlihat bahwa $F_{\text {hitung }}>F_{\text {tabel }}(3,6098<2,75)$ maka dapat dikatakan bahwa secara simultan debt to equity ratio, return on assets dan current 
ratio berpengaruh signifikan terhadap price to book value. Temuan ini menunjukkan bahwa dengan adanya price to book value dapat dijelaskan oleh adanya variabel debt to equity ratio, return on assets dan current ratio. Adapun besarnya kontribusi dari variabel debt to equity ratio, return on assets dan current ratio dalam menjelaskan variabel price to book value dapat dilihat dari nilai $r$ square dari metode $M$ Estimation =0,133981 (13,3981\%). Dengan demikian semua variabel bebas yang digunakan dalam penelitian ini hanya mampu menjelaskan variabel price to book value sebesar 13,3981\% saja, sedangkan sisanya dijelaskan oleh variabel lain diluar model.

\section{KESIMPULAN DAN SARAN}

Kesimpulan yang dihasilkan dari analisis data dan pembahasan di bagian sebelumnya yaitudimana Debt to equity ratio secara parsial berpengaruh positif namun tidak signifikan terhadap price to book value sub sektor Makanan dan Minuman periode 2013-2017. Selain itu, Return on assets secara parsial berpengaruh positif dan signifikan terhadap price to book value sub sektor Makanan dan Minuman periode 2013-2017. Serta current ratio secara parsial berpengaruh negatif namun tidak signifikan terhadap price to book value sub sektor Makanan dan Minuman periode 2013-2017. Dan juga debt to equity ratio, return on assets dan current ratio secara simultan berpengaruh signifikan terhadap price to book value sub sektor Makanan dan Minuman periode 2013-2017.

Temuan ini mengimplikasikan bahwa semakin tinggi return on assets perusahaan maka akan secara signifikan membuat nil ai perusahaan yang dapat dilihat dari price to book value semakin tinggi, namun dengan perubahan current ratio dan debt to equity ratio tidak memberikan dapatk yang signifikan terhadap perubahan dari price to book value. Untuk itu, sebagai upaya dalam meningkatkan nilai perusahaan secara signifikan perusahaan terdaftar di Bursa Efek Indonesia dapat menfokuskan pada peningkatan profitabilitas perusahaan khususnya pada rasio return on asset.Bagipeneliti selanjutnya diharap dapat meneliti dengan mengambil populasi yang lebih besar lagi misalnya dengan mengambil beberapa sektor perusahaan di BEI dengan membandingkan price to book value dari setiap sektornya. Selain itu, hasil penelitian ini menghasilkan nilai R Square yaitu 0,133981yang artinya masih banyak lagi variabel yang dimungkinkan berpengaruh terhadap price to book value selain variabel yang diteliti seperti good corporate governance, kualitas laba dan sebagainya.

\section{REFERENSI}

Anjarwati, K., Chabachib, M. \& Demi, I. R. 2016. Pengaruh Profitabilitas, Size, Dan Likuiditas Terhadap Nilai Perusahaan Manufaktur Di Indonesia Dengan Struktur Modal Sebagai Variabel Intervening (Studi Empiris Pada Perusahaan Manufaktur yang Terdaftar di Bursa Efek Indonesia Tahun 2012-2015). Diponegoro Journal of Finance.

Brigham, E. F \& Houston, J. F. 2015. Fundamentals of Financial Management, Eleventh Edition. United States of America: Thomson South-Western.

Ehrhardt, M. C \& Brigham, E. F. 2011. Financial Management: Theory and Practice, Thirteenth Edition. Canada: Nelson Education, Ltd.

Euis, S. \& Taswan. 2002. Pengaruh Kebijakan Hutang Terhadap Nilai Perusahaan Serta Beberapa Faktor Yang Mempengaruhinya. Jurnal Bisnis dan Ekonomi.

Fadhli, M. 2014. Pengaruh Likuiditas, Solvabilitas Dan Profitabilitas Terhadap Nilai Perusahaan Dengan Kebijakan Dividen Sebagai Variabel Moderasi Pada Perusahaan Perbankan, Asuransi \& Lembaga Keuangan Lainnya Di Bursa Efek Indonesia Tahun 2010-2013. Jom Fekon, Vol.2 No.2, h.1-14.

Fahmi, I. 2012. Pengantar Pasar Modal. Bandung : Alfabeta. 
Hamidy, R. R., Wiksuana, G. B. \&Artini, L. G. S. 2015. Pengaruh Struktur Modal Terhadap Nilai Perusahaan Dengan Profitabilitas Sebagai Variabel Intervening Pada Perusahaan Properti Dan Real Estate Di Bursa Efek Indonesia. E-Jurnal Ekonomi dan Bisnis Universitas Udayana, Vo.4, No.10, h.665-682.

Jibran, S., Wajid, S. A., Waheed, I. \&Muhammad, T. M. 2012. Pecking at Pecking Order Theory: Evidence from Pakistan's Non-financial Sector. Journal of Competitiveness, Vol.4, No. 4, Hal. 86-95.

Kasmir. 2017. Analisis Laporan Keuangan. Jakarta: PT Raja Grafindo Persada.

Lubis, I. L., Sinaga, B. M. \& Sasongko, H. 2017. Pengaruh Profitabilitas, Sruktur Modal, Dan Likuiditas Terhadap Nilai Perusahaan. Jurnal Aplikasi Bisnis dan Manajemen, Vol. 3 No. 3, h.458-465.

Paramasivan, C \&Subramanian, T. 2012. Financial Management. New Dehi: New Age International (P) Limited, Publishers.

Shahar, W. S. S.\& Bahar, N. F. 2015. A Review Of Capital Structure Theories: Trade-Off Theory, Pecking Order Theory And Market Timing Theory. Proceeding of the $2^{\text {nd }}$ International Conference on Management and Muamalah.

Susanti, Y., Pratiwi, H., Sulistyowati, S. \& Liana, T. 2014. M Estimation, S Estimation, And Mm Estimation In Robust Regression. International Journal of Pure and Applied Mathematics, Vol.91, N0.3, h.349-360.

Wijaya, I. B. N. P. \& Purnawati, N. K. Pengaruh Likuiditas Dan Kepemilikan Institusional Terhadap Nilai Perusahaan Dimoderasi Oleh Kebijakan Dividen. Jurnal Ekonomi dan Bisnis, Universitas Udayana.

Zhao, J., Katchova, A. L.\& Barrt, P. J. 2004. Testing the Pecking Order Theory and the Signaling Theory for Farm Businesses. Selected Paper prepared for presentation at the American Agricultural Economics Association Annual Meeting, Denver, Colorado. 